\title{
The Design Of Grain Drying Oven Using Residual Exhaust Gas From Diesel Engine With Heat Transfer Analysis
}

\author{
Peter Sahupala ${ }^{l, *}$, Daniel Perenden ${ }^{l}$, Christian Wely Wullur ${ }^{l}$ \\ 1,Department of Mechanical Engineering, Faculty of Engineering, Musamus Merauke University , Jln. Kamizaun, \\ Merauke, Postal Code: 99616
}

\begin{abstract}
The drying process plays an important role in the preservation of agricultural products. To this day, the drying process of rice grains harvested by the farmers in Semangga District, Merauke Regency, has always used sunlight. However, during rainy season, the farmers cannot dry their grains, and if such thing happens for a long time, it will cause decayed grains. The drying characteristics of a material are necessary in designing the dryers in use. The method used in this research was the design of grain dryers, which took the form of heating oven, by utilizing heat from the residual exhaust gas of diesel engine. The exhaust gas coming out of the exhaust manifold would be flowed through the heating pipe in the oven heating chamber, then through the convective heat transfer process, followed by conductive heat transfer, and then the heat flow conduction would be transmitted to the drying chamber. The objective of this research was to design grain dryers by using Diesel engine's residual exhaust gas, and to calculate the efficiency of grain dryer using heat transfer analysis. The bulk gas temperature in the exhaust gas section for hot fluid in the pipe is $371.55 \mathrm{~K}$ at a motor rotation of $2400 \mathrm{rpm}$, with the flow rate of the incoming exhaust gas heat mass of $0.01798031 \mathrm{~kJ} / \mathrm{s}$. The velocity of incoming exhaust gas mass is $36.75 \mathrm{~kg} / \mathrm{s}$, with the comprehensive heat transfer coefficient on the inlets of $92.7334404 \mathrm{~W} / \mathrm{m}^{2} . \mathrm{oC}$. The heat transfer in the air section/ fluid section in the inner pipe is $351.1351 \mathrm{~K}$, while the convective heat transfer coefficient in exit pipe is $8.010580984 \mathrm{~W} / \mathrm{m}^{2} .^{\circ} \mathrm{C}$, thus obtaining Comprehensive heat transfer of $40.2312698 \mathrm{~W} / \mathrm{m}^{2} .{ }^{\circ} \mathrm{C}$. The logarithmic mean temperature difference (LMTD) in the evaporator is $35.69590751^{\circ} \mathrm{C}$ with total heat transfer area of $084178 \mathrm{~m}^{2}$. With $2400 \mathrm{rpm}$ motor rotation, the total heat transfer at the heat exchanger, which is the usable maximum heat, is equal to $0.226296111 \mathrm{~kW}$; while the effectiveness of heat exchanger is at $60.95 \%$. The energy used to evaporate the water and the amount of convective heat transfer from dry air to the product are $0.03696 \mathrm{~kW}$, while the amount of air energy used is $0.05150 \mathrm{~kW}$, obtaining the efficiency of the drying machine at $71 \%$.
\end{abstract}

\section{INTRODUCTION}

Agricultural products, including grains or cereal crops, such as corn, grain/ rice, beans, coffee, etc. require more serious attention, especially in the preservation process. The drying process plays an important role in the preservation of agricultural products. The drying characteristics of a material are necessary in designing and operating the dryers in use.

Drying process of grains is generally done by using solar energy. Nevertheless, this method highly depends on the season, drying time, large number of workers, and extensive place. The drying process of high-moisture grain can be conducted in two ways: long period of drying process at low temperature, or shorter period of drying process at higher temperature. However, if the drying process done to a material takes too much time at low temperature, the microorganism activity happens very quickly, for instance the growing molds or spoilage. On the contrary, drying process at excessively high temperature may cause damage to the components of materials being dried, both physically and chemically. Therefore, it is necessary to choose an effective and efficient drying method to avoid damage in agricultural products.

The drying process of agricultural products done by farmers in Indonesia, especially in Merauke Regency, Semangga District, still utilizes solar energy as its drying

\footnotetext{
* Corresponding author:louissahupala@gmail.com
}

power. Still, during the rainy season, they have difficulty to dry agricultural produce due to the lack of sunlight with adequate intensity as a source of heat. If the agricultural products are not drained properly up to certain moisture content, they will germinate, or even become decayed from microorganism's metabolic activity, downgrading their quality. As an alternative solution to this problem, it is necessary to conduct a study to design a drying tool capable of assisting the farmers to dry their agricultural products, especially grains. The drying tool to be examined for its drying characteristics is a tray dryer, which uses remaining exhaust gas from Diesel motor as a drying medium. The tool is expected to dry the agricultural products with evenly-distributed dryness level (moisture content) on the materials.

The exhaust heat generated by Diesel Engine still contains plenty of usable heat/ thermal energy, because $34-40 \%$ of energy from the combustion in motor is wasted through exhaust gas. Such energy can be utilized as a source of heat energy for the grain drying process, through the process of heat removal from a closed container to the dryer. It is expected that this research can provide a good and useful contribution in the utilization of wasted energy for agricultural product drying process.

Alternative technology is designed in the form of dryer oven using residual exhaust gas from Diesel motor. 
This drying tool will be placed on a rice mill, where Diesel motor is used as the driver. The exhaust manifold duct from the Diesel motor will be made circular, which passes through the drying oven chamber, where the heat energy will be removed from the exhaust manifold to the drying oven chamber for the grain drying process. The farmers, therefore, can directly use the energy from the rice milling process, which is more efficient yet requires no substantial cost in maintaining rice quality.

The amount of water content in grain is called moisture content, and is described by percent (\%). Drying process is necessary due to high moisture content of grain, where in general, grain's moisture content reaches $20 \%-26 \%$ that certainly depends on the weather at the time of harvesting.

The grain drying process is a treatment aimed at reducing the moisture content for longer grain storage, to keep the germination away, to maintain quality of the grain (not yellow, not germinate, and not moldy), to facilitate the milling process, and to increase the yield quality and produce good milled rice.

As the purposes of drying process, besides reducing transportation costs, are also meant to reduce the moisture content from $23-27 \%$ to $14 \%$, and to produce good quality rice for longer grain storage. Grain drying process should be done evenly and slowly at a moderate temperature. Uneven drying will cause cracks in the grain, and the same will apply to the opposite: overly dried grain will easily break when milled. Meanwhile, in an overly wet condition, the grain will be difficult to grind and is also deficient in term of storage quality, as it will be easily attacked by warehouse pests, fungus and mushrooms (Strumillo and Kudra, 1986).

\section{Drying Methods}

\section{Natural Drying Process}

According to Widiastuti (1980), drying methods are divided into:

1) Drying method on the floor

2) Drying method on the shelf

3) Drying method with stacked bundles

4) Drying method with bundles standing upright

5) Drying method using wooden stakes

Grain drying process on the drying floor (reported) is a practical, cheap, simple natural way of drying grain that is commonly used by farmers. The energy for evaporation is obtained from the wind and sunlight. The mat must be clean so that dried rice grain won't be dirty, and it must also be adequate, for instance: does not cause too much heat, easy to clean and dry, not wet when used, and has no potholes. It is generally made of cement of which surface is slightly tilted and wavy. Such thing is meant to prevent the mat from filled with water, make it easier to dry and expand the surface. The drying process is done by spreading the grain across the mat to form a layer as thin as possible, but for efficiency and to reduce the effect of the overly hot cement floor, the grain layer is recommended to be approx. $5-7 \mathrm{~cm}$. Rice grain should often be evenly flipped back and forth for at least 2 hours. The drying process can be done for
1-3 days, depending on the weather (cloudy or sunlight). Drying process should be done in a place that is free to receive sunlight, free of flood and free from disturbance of poultry and other pest animals.

Natural drying process has the following disadvantages: (a) it requires many workers to spread, flip and recollect the grains, (b) it is heavily dependent on the weather, making it impossible to do under bad weather, especially when it comes to drying process, c) requires a large area of land for large quantities of paddy grains, and cement mat can no longer be used for other purposes; (d) it is difficult to regulate the temperature and drying rate on cement or metal mats (Widjono et al.)

\section{Artificial Drying Process}

Artificial drying process has advantages over natural one, in a way that it takes shorter drying time and the dried grain will be cleaner and more protected from dust, rain and others. There are various types artificial drying process, for example those using electricity, sun, husk fuel and others (Setijahartini, 1980).

\section{Theory of Drying}

The drying process is the poses of receding moisture content of a material to the predetermined limit of the moisture content. In wet basis, the amount (mass) of evaporated water is calculated based on the initial mass water difference (mw1) and the final water mass $\left(\boldsymbol{m} \boldsymbol{w}_{2}\right)$.

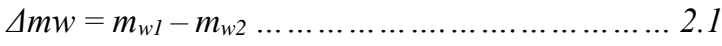

$$
\begin{aligned}
& \text { Where: } \\
& \Delta m w=\text { evaporated water mass } \\
& \text { during the drying process. } \\
& m_{w 1}=\text { initial water mass } \\
& m_{w 2}=\text { final water mass } \\
& \text { where: } \\
& m_{w l}=\text { Ko } x m
\end{aligned}
$$

Final moisture content $(K)$ is obtained using this equation:

K

$$
=\frac{m_{w 2}}{m_{w 2}+m d}
$$

Where :

$K=$ moisture content after drying process (5) $m d=$ material dry mass obtaining :

$$
\begin{aligned}
& m_{w 2} \\
& =\frac{K \cdot m d}{1-K} \text { Where : } \\
& \Delta m_{w}=K o \cdot m \frac{K \cdot m d}{1-K} \\
& \Delta m_{w}=\frac{K o \cdot m(1-K)-K \cdot(m-K o \cdot m)}{1-K} \\
& \Delta m_{w} \\
& =\frac{m(K o-K)}{1-K}
\end{aligned}
$$

The equation above is used to calculate the 
evaporated water mass into a material in the drying process (Henderson and Perry, 1976).

The moisture content of a material can be described in wet base or dry base. The moisture content in the wet base represents the ratio of water mass in the material to the total mass of the material. At dry basis, the moisture content is calculated by dividing the water mass of the material by its dry mass alone. Both wet base and dry base are described in humidity percentage:

$\mathrm{Mw}=$ wet basis

$$
M w=\frac{m w}{m w+m d}
$$

$\mathrm{mw}=$ water mass

md $=$ material dry mass

$$
M w=\frac{m w}{m d}
$$

\section{Heat Transfer on Destilator}

a. Conductive Heat Transfer

Conduction is the process by which heat flows from a higher temperature area to the lower one within one medium (solid, liquid or gas) or between different mediums directly intersecting (Frank Kreiht 1991).

In the heat flow of conduction, energy transfer occurs because of direct molecular relationship in the absence of large molecular displacements. According to kinetic theory, the element temperature of a substance is proportional to the average kinetic energy of the molecules that make up the element. Conduction is the only mechanism by which heat can flow in an opaque solid.

Under the second law of thermodynamic, heat will flow automatically from a point of higher temperature to a lower temperature point, and then the heat flow will be positive when the temperature gradient is negative.

\section{b. Convective Heat Transfer}

Convection is the energy transport process with a work combination of heat conduction, energy storage and mixing motion. Convection is important as a mechanism of energy transfer between the surface of solid objects, liquids and gases (Frank Kreiht, 1991).

Convective heat transfer is classified in free convection and forced convection. If the fluid motion takes place solely as a result of the difference in the density caused by the temperature gradient, then the process is called free convection. And if the fluid motion is caused by external device, such as a pump or fan, then the process is called forced convection (Frank Kreiht, 1991).

$\mathrm{q}=\mathrm{h}(\mathrm{Tw}-\mathrm{Tf})$

And convective heat transfer from hot fluid to cool wall can be written as follows:

$\mathrm{q}=\mathrm{h}$. A. $\left(\mathrm{Tf}-\mathrm{T}_{\mathrm{w}}\right)$

where :

$\mathrm{q}=$ rate of convective heat flow (Watt)

$\mathrm{A}=$ cross-sectional area perpendicular to the direction of heat flow $\left(\mathrm{m}^{2}\right)$

$\mathrm{h}=$ convective heat transfer coefficient $\left(\mathrm{W} / \mathrm{m}^{2} \mathrm{~K}\right)$

$\mathrm{T}_{\mathrm{w}}=$ surface temperature $(\mathrm{K})$

$\mathrm{Tf}=$ cool fluid temperature $(\mathrm{K})$

\section{Heat transfer coefficient outside of the pipe}

The heat transfer coefficient in this analysis is free convective heat transfer from heating process, so that the fluid changes its density and moves up the surface. Fluid motion in free convection, both in gas and liquids, occurs because of the buoyant force they experience when the fluid density near the surface of heat transfer is reduced as a result of the heating process.

Convective heat transfer coefficient can be calculated by the following equation:

$$
\begin{aligned}
& R a=G r \cdot P r \\
& =\frac{g \cdot \beta \cdot\left(T_{w}-T_{a}\right) \cdot d o^{3}}{v^{2}} \cdot \operatorname{Pr}
\end{aligned}
$$

$\mathrm{Nu}$

$$
=0,53 x(G r \cdot P r)^{\frac{1}{4}}
$$

So the convective heat transfer coefficient is:

ho

$=\frac{N u \cdot k}{d o}$

\section{Comprehensive Heat Transfer Coefficient}

The rate of heat transfer going through the pipe surface can be seen in the figure below:

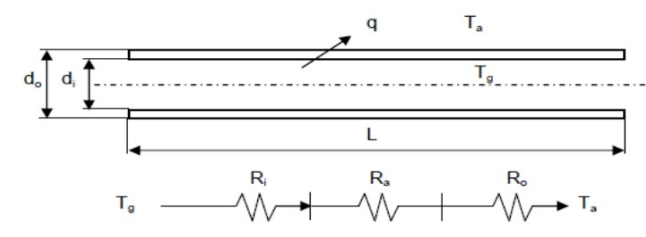

Figure 2.1. The process of heat transfer in the pipe and its thermal resistance

Where :

$$
\begin{aligned}
& \mathrm{Ri}=\mathrm{Rth}=\text { Inner pipe convection }=\frac{1}{\left(2 \pi \cdot r_{1} \cdot L \cdot h_{i}\right)} \\
& \mathrm{Ra}=\mathrm{Rth}=\text { Material conduction }=\ln \left[\frac{\left(\frac{r_{O}}{r_{i}}\right)}{(2 \pi \cdot k \cdot L)}\right] \\
& \mathrm{Ri}=\mathrm{Rth}=\text { outer convection }=\frac{1}{\left(2 \pi \cdot r_{O} \cdot L \cdot h_{o}\right)}
\end{aligned}
$$

The sum of these three equations is then entered into the following equation $U=\frac{1}{A \cdot \bar{\Sigma} R_{t h}}$ where A which usually takes the outer surface area $\left(\mathrm{A}_{\mathrm{o}}\right)$ results in:

$$
=\frac{1}{\frac{r_{o}}{r_{i} \cdot h_{i}}+\frac{r_{o}}{2 x k} \times \ln \frac{r_{0}}{r_{i}}+\frac{1}{h_{o}}}
$$

Thus the radius (r) is described in diameter (d) of the pipe, where $\mathrm{d}=2 . \mathrm{r}$ and the equation above will be:

$$
U=\frac{1}{\frac{d_{o}}{d_{i} \cdot h_{i}}+\frac{d_{o}}{2 x k} x \ln \frac{d_{o}}{d_{i}}+\frac{1}{h_{o}}}
$$

\section{Logarithmic Mean Temperature Difference ( $\left.\mathbf{T}_{\text {LMTD }}\right)$}

The fluid temperature inside the heat exchanger is generally non-constant, but differs from one point to another when heat flows from the hotter fluid to the cooler one. Thereby, even for any constant thermal 
resistance, the heat flow rate will vary along the path of the heat exchanger, as the price depends on the temperature difference between the hot and cold fluid in a particular cross section.

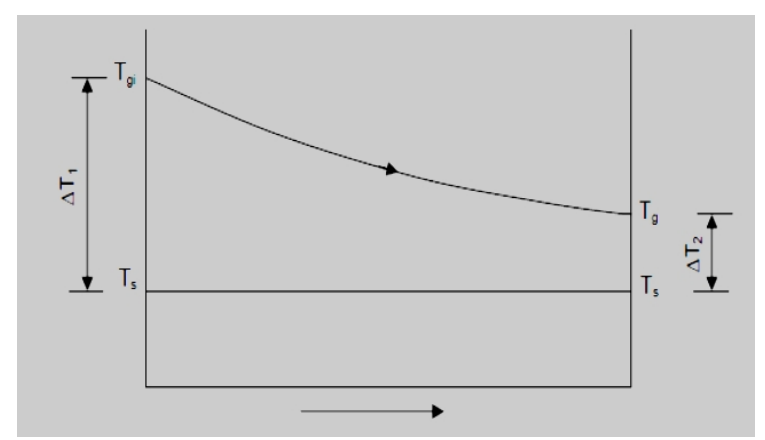

Figure 2.2. Temperature distribution in the distillation pipe

The figure above shows a case where liquid evaporates at a constant temperature, whilst heat flows from a hotter fluid with decreasing temperature, as long as the fluid passes through the heat exchanger. In this case, the fluid flow is not a problem and the medium with constant temperature may not move.

$$
\begin{aligned}
& \Delta T_{L M T D} \\
& =\frac{\Delta T_{1}-\Delta T_{2}}{\ln \left(\frac{\Delta T_{1}}{\Delta T_{2}}\right)}
\end{aligned}
$$

Where :

$$
\begin{aligned}
& \Delta \mathrm{T}_{1}=\mathrm{T}_{\mathrm{gi}}-\mathrm{T}_{\mathrm{s}} \\
& \Delta \mathrm{T}_{2}=\mathrm{T}_{\mathrm{go}}-\mathrm{T}_{\mathrm{s}}
\end{aligned}
$$

\section{Total Heat Transfer}

The analysis of total heat exchanger uses the following equation:

$\mathrm{Q}_{\text {tot }}=\mathrm{U}_{\text {tot }} \times \mathrm{A}_{\text {tot }} \mathrm{x} \Delta \mathrm{T}_{\mathrm{LMTD}}$

Where :

$\mathrm{U}_{\mathrm{tot}}=$ coefficient of comprehensive heat transfer

$\left(\mathrm{W} / \mathrm{m}^{2} \mathrm{C}\right)$

$\mathrm{A}_{\text {tot }}=$ heat transfer surface area $\left(\mathrm{m}^{2}\right)$

$=\pi \cdot \mathrm{d}_{\mathrm{o}} \cdot \mathrm{n} \cdot \mathrm{L}$

$\mathrm{n}=$ number of pipe

$\mathrm{d}_{\mathrm{o}}=$ outer diameter of pipe $(\mathrm{m})$

$\mathrm{L}=$ pipe length $(\mathrm{m})$

\section{Energy Balance}

The energy balance can be determined by calculating the heat of exhaust gas $\left(\mathrm{Q}_{\mathrm{gbi}}\right)$; the absorbed heat or the heat entering the grain drying chamber $\left(\mathrm{Q}_{\mathrm{abs}}\right)$; the outer heat coming towards the fan into the air environment $\left(\mathrm{Q}_{\mathrm{gbo}}\right)$; the heat loss in the drying chamber's wall $\left(\mathrm{Q}_{\mathrm{d}}\right)$; and the total loss of other heats ( $\left.\mathrm{Q}_{\text {losses }}\right)$.

1. Total heat of exhaust gas coming towards heating chamber

$\mathrm{Q}_{\mathrm{gbt}}=\mathrm{m}_{\mathrm{g}} \cdot \mathrm{Cpg} \cdot \mathrm{T}_{\mathrm{gbt}}$

2. Total heat of absorbed exhaust gas

$\mathrm{Q}_{\mathrm{abs}}=\mathrm{m}_{\mathrm{a}} \cdot \mathrm{C}_{\mathrm{pa}} \cdot\left(\mathrm{T}_{\mathrm{s}}-\mathrm{T}_{\mathrm{a}}\right)+\mathrm{m}_{\mathrm{a}} \mathrm{h}_{\mathrm{fg}}$

3. Total heat of exhaust gas coming towards heat flow discharge fan into the environment

$\mathrm{Q}_{\mathrm{gbo}}=\mathrm{m}_{\mathrm{g}} \cdot \mathrm{C}_{\mathrm{pg}} \cdot \mathrm{T}_{\mathrm{gbo}}$

4. Losses of other heats (losses)

$\mathrm{Q}_{\mathrm{gbt}}=\mathrm{Q}_{\mathrm{abs}}+\mathrm{Q}_{\mathrm{gbo}}+\mathrm{Q}_{\text {losses }}$
$\mathrm{Q}_{\text {losses }}=\mathrm{Q}_{\mathrm{gbt}}+\left(\mathrm{Q}_{\mathrm{abs}}+\mathrm{Q}_{\mathrm{gbo}}\right)$

\section{RESEARCH METHODOLOGY}

\section{Tool and Materials}

The tools used in this research were grain dryer with the type batch dryer (lab scale), scales, stopwatch, fan, thermometer, and Diesel motor $\pm 12 \mathrm{HP}$.

The material used in this research was wet grain (post-harvest) of $\pm 10 \mathrm{~kg}$. The grain was obtained from the farmers in agricultural area of SP II Tanah Miring District.

\section{Research Procedure}

The research procedure included the preparation of tools and materials, implementation and parameter measurement, the grain weight before and after the drying process, and the temperature at the points to be determined.

\section{Research Implementation}

The manufacture of batch dryer

The dryer made based on their function and size can be divided into several sections: drying chamber, drying pad, manifold channel/pipe, fan, and Diesel motor.

a. Drying chamber

The drying chamber is a part of the whole body, while the drying section includes drying pad. It serves to dry material of which hot air comes from the plenum chamber. The drying chamber is made of wooden plywood coated with Styrofoam and aluminum foil to maintain the heat indoors. It is made $90^{\circ}$ with a thickness of $1 \mathrm{~cm}$ and $5 \mathrm{~cm}$ wide, while the drying chamber is designed in rectangular shape with dimension of $100 \mathrm{~cm}$ x $32 \mathrm{~cm} \mathrm{x} 10 \mathrm{~cm}$.

b. The drying pad serves as a place to withstand the dried material and pass through the hot air. The drying base is located in the drying room, just above the plenum. The drying pad is made of an elbow iron of $2 \mathrm{~mm}$ as the frame, and the bottom is equipped with zinc plate as the drying pad.

c. Exhaust fan

Exhaust fan is a fan that serves as air vacuum in the chamber to discharge the air, while sucking fresh air into the chamber. Exhaust fan needs electric power and can blow and suck air, allowing air circulation in the chamber run faster and more optimally. Exhaust fan motor is equipped with safety fuse. So, if it becomes heated from working overtime, the motor won't be damaged and the only thing broken will be the fuse. The motor also has a lubrication system to keep the motor running smoothly (Anonymous, 2008).

This research was designed in 3 (three) treatments for the grain drying process: $1 \mathrm{~kg}, 5 \mathrm{~kg}$ and $15 \mathrm{~kg}$. This research was started by entering grain into the drying chamber. The heat flow was obtained from the exhaust gas from the combustion of the Diesel motor flowing through the manifold pipe connected in the grain drying chamber. Drying process would continue until the grain's moisture content become $13 \%-14 \%$. 


\section{Data Collection Method}

The methods carried out in this research were:

a. Field study: conducted by taking the data directly from the object to be observed according to the field. Direct recording was done in the study site to obtain the required data.

b. Literature review of the theories underlying the issues raised.

\section{Data Analysis Method}

After the entire research data had been collected, the next step to do was analyzing the experiment data. The analytical method used was: the grain given with heat treatment would be calculated using wet base, while for flow rate of heat transfer, it would be analyzed by conduction analysis and convection analysis.

\section{Research Flow Diagram}

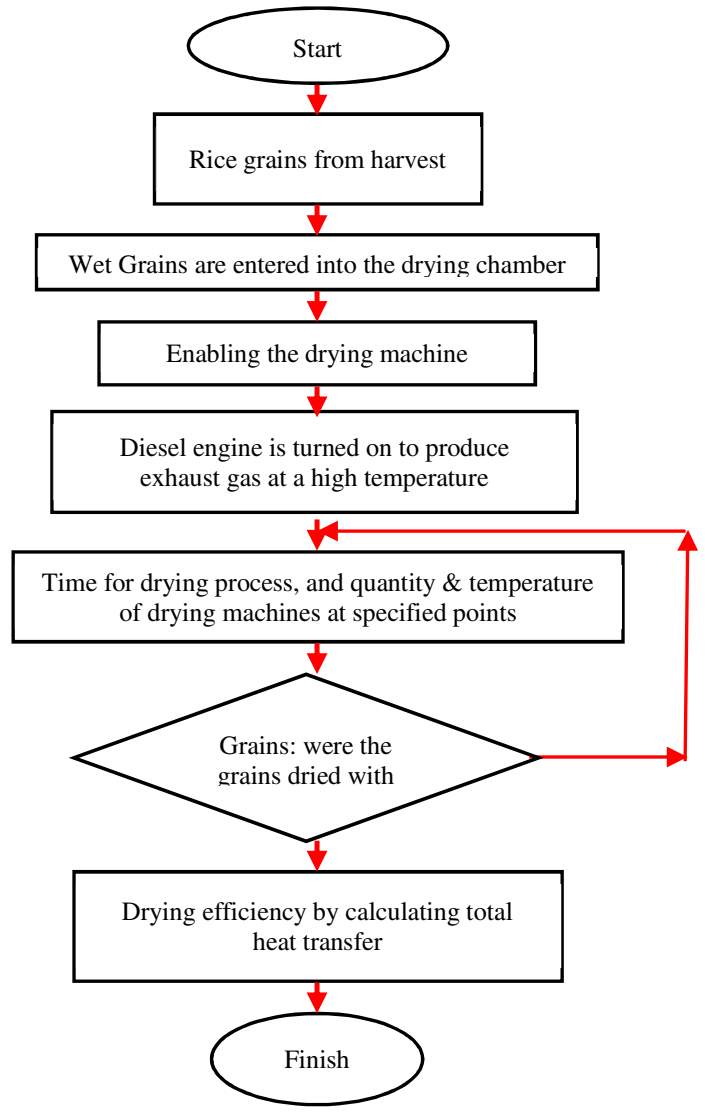

\section{RESULT AND DISCUSSION}

The research was conducted on July 10, 2017, and was begun by discussing the design on the grain drying oven and job division, followed by preparation of the research, and procurement of materials for the tool manufacturing process. The design of the tool was made to accommodate $\pm 5 \mathrm{~kg}$ of grain, with the shelf measured to $65.5 \mathrm{~cm} \mathrm{x} 58.5 \mathrm{~cm}$.

The data collection was carried out for 3 days to obtain more accurate data, and then the dried grain was tested for its moisture content in agricultural laboratories.

The study was conducted for 3 days to get more accurate drying results. Before the drying process, the grain was found to weigh $3 \mathrm{~kg}$. The grain was subsequently entered into the oven for drying process.

\begin{tabular}{|c|l|l|}
\hline $\begin{array}{c}\text { Experime } \\
\text { nt No. }\end{array}$ & \multicolumn{2}{|c|}{ Temperature Parameter } \\
\hline \multirow{5}{*}{ I } & Weight & $3 \mathrm{Kg}$ \\
\cline { 2 - 3 } & Room Temperature & $28,9^{0} \mathrm{C}$ \\
\cline { 2 - 3 } & Machine Temperature & $93,5^{0} \mathrm{C}$ \\
\cline { 2 - 3 } & Exit pipe temperature & $110,6^{0} \mathrm{C}$ \\
\cline { 2 - 3 } & Pipe temperature in the Oven & $57,2^{\circ} \mathrm{C}$ \\
\cline { 2 - 3 } & Oven Temperature & $46,8^{0} \mathrm{C}$ \\
\cline { 2 - 3 } & Grain Temperature & $40,6{ }^{0} \mathrm{C}$ \\
\hline \multirow{5}{*}{ II } & Machine Temperature & $113^{0} \mathrm{C}$ \\
\cline { 2 - 3 } & Exit pipe Temperature & $110,6{ }^{0} \mathrm{C}$ \\
\cline { 2 - 3 } & Pipe temperature in the Oven & $57,6{ }^{0} \mathrm{C}$ \\
\cline { 2 - 3 } & Oven Temperature & $51,6^{0} \mathrm{C}$ \\
\cline { 2 - 3 } & Grain Temperature & $45,3{ }^{0} \mathrm{C}$ \\
\hline \multirow{5}{*}{ III } & Machine Temperature & $109{ }^{0} \mathrm{C}$ \\
\cline { 2 - 3 } & Exit pipe temperature & $118,8^{0} \mathrm{C}$ \\
\cline { 2 - 3 } & Pipe temperature in the Oven & $58,9 \mathrm{C}$ \\
\cline { 2 - 3 } & Oven Temperature & $51,6 \mathrm{C}$ \\
\cline { 2 - 3 } & Grain Temperature & $48,3 \mathrm{C}$ \\
\hline
\end{tabular}

In this 45-minutes experiment, the grain weighted $2.589 \mathrm{~kg}$.

\section{Experiment to Grain Moisture Content}

This calculation is performed on steady condition with motor rotation of $2400 \mathrm{rpm}$, and the data obtained from the research are as follows:

a. Gas temperature entering the evaporator $\left(\mathrm{T}_{\mathrm{gi}}\right)$ : $118,8^{\circ} \mathrm{C}$

b. Gas temperature coming out of the evaporator $\left(\mathrm{T}_{\mathrm{go}}\right)$ : $78^{\circ} \mathrm{C}$

c. Pipe surface temperature $\left(\mathrm{T}_{\mathrm{w}}\right): 97^{\circ} \mathrm{C}$

d. Evaporator temperature $\left(\mathrm{T}_{\mathrm{a}}\right): 58,9^{\circ} \mathrm{C}$

e. Grain temperature $\left(\mathrm{T}_{\mathrm{g}}\right): 48,3^{\circ} \mathrm{C}$

f. Weight of grain before drying process : $3 \mathrm{~kg}$

g. Weight of grain before drying process (1 hour): $2,625 \mathrm{~kg}$

h. Outer diameter of heating pipe $\left(\mathrm{d}_{\mathrm{o}}\right): 2,72 \mathrm{~cm}$

i. Inner diameter of heating pipe $\left(\mathrm{d}_{\mathrm{i}}\right): 2,54 \mathrm{~cm}$

j. Diesel motor rotation used: $2400 \mathrm{rpm}$

\begin{tabular}{|c|l|c|l|}
\hline No & \multicolumn{1}{|c|}{$\begin{array}{c}\text { Calculation } \\
\text { Parameter }\end{array}$} & $\begin{array}{c}\text { Calculatio } \\
\text { n results }\end{array}$ & Unit \\
\hline Gas Section Inside the Pipe \\
\hline 1. & $\begin{array}{l}\text { Bulk temperature } \\
\text { of exhaust gas }\end{array}$ & 371.55 & $\mathrm{~K}$ \\
\hline 2. & $\begin{array}{l}\text { Mass Flow Rate of } \\
\text { Exhaust Gas }\end{array}$ & 0,01798031 & $\mathrm{Kg} / \mathrm{s}$ \\
\hline 3. & $\begin{array}{l}\text { Velocity of Gas } \\
\text { Mass }\end{array}$ & 36,75 & $\mathrm{Kg} /{\mathrm{s} . \mathrm{m}^{2}}^{2}$ \\
\hline 4. & Reynolds Number & 34614,2653 & \\
\hline 5. & Nusselt Number & 76,4348357 & - \\
\hline 6. & $\begin{array}{l}\text { Comprehensive } \\
\text { Transfer } \\
\text { Coefficient }\end{array}$ & 92,7334404 & $\mathrm{~W} / \mathrm{m}^{2} .^{\circ} \mathrm{C}$ \\
\hline
\end{tabular}




\begin{tabular}{|c|c|c|c|}
\hline \multicolumn{4}{|c|}{ Hot Fluid Section Outside the Pipe } \\
\hline 7. & $\begin{array}{ll}\text { Hot } & \text { fluid } \\
\text { temperature }\end{array}$ & 351.1351 .13 & $\mathrm{~K}$ \\
\hline 8. & Reynolds Number & 1909.08474 & - \\
\hline 9. & Nusslt Number & 7,02863879 & 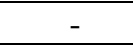 \\
\hline 10. & $\begin{array}{l}\text { Convective heat } \\
\text { transfer coefficient }\end{array}$ & 8,01058098 & $\mathrm{~W} / \mathrm{m}^{2} .^{\circ} \mathrm{C}$ \\
\hline 11. & $\begin{array}{l}\text { Comprehensive } \\
\text { Heat Transfer } \\
\text { Coefficient }\end{array}$ & 40,2312698 & $\mathrm{~W} / \mathrm{m}^{2} .^{\circ} \mathrm{C}$ \\
\hline 12. & $\begin{array}{l}\text { Logarithmic mean } \\
\text { temperature } \\
\text { difference }\end{array}$ & 35,6959075 & $\mathrm{~K}$ \\
\hline 13. & $\begin{array}{l}\text { Total heat transfer } \\
\text { area }\end{array}$ & 84178 & $\mathrm{M}^{2}$ \\
\hline 14. & $\begin{array}{l}\text { Total heat transfer } \\
\text { on heat exchanger }\end{array}$ & 0,22629611 & $\mathrm{~kW}$ \\
\hline 15. & $\begin{array}{l}\text { Effectiveness of } \\
\text { heat exchanger }\end{array}$ & 60,95 & $\%$ \\
\hline \multicolumn{4}{|c|}{ Drying Process } \\
\hline 16. & $\begin{array}{l}\text { Percentage of wet } \\
\text { base moisture } \\
\text { content }\end{array}$ & 0,766 & $\%$ \\
\hline 17. & $\begin{array}{l}\text { Percentage of dry } \\
\text { base moisture } \\
\text { content }\end{array}$ & 2,248 & $\%$ \\
\hline 18. & $\begin{array}{l}\text { The amount of } \\
\text { evaporating water }\end{array}$ & 2,125 & $\mathrm{Kg}$ \\
\hline \multicolumn{4}{|c|}{ Energy used to evaporate water } \\
\hline 19. & $\begin{array}{l}\text { Amount of } \\
\text { convective heat } \\
\text { transfer from air to } \\
\text { product }\end{array}$ & 0,03696 & $\mathrm{~kW}$ \\
\hline 20. & The energy used & 0,03696 & $\mathrm{~kW}$ \\
\hline 21. & Tool efficiency & 71 & $\%$ \\
\hline
\end{tabular}

From result of the analysis conducted, it is shown that bulk gas temperature at gas exhaust section for hot fluid in the pipe is equal to $371,55 \mathrm{~K}$ at motor rotation of $2400 \mathrm{rpm}$ with rate of mass flow of exhaust gas entering $0,01798031 \mathrm{~kJ} / \mathrm{s}$. The exhaust gas mass velocity of 36.75 $\mathrm{kg} / \mathrm{s}$ with comprehensive heat transfer coefficient on the inlet of $92.7334404 \mathrm{~W} / \mathrm{m}^{2}{ }^{\circ} \mathrm{C}$. The result above indicates that the higher the rotation of the motor, the greater the hot gas flow in the pipe; and the rise in temperature will follow the gas flow rate, thus obtaining greater heat transfer rate. Therefore, it can be said that the higher the rotation of the motor, the greater the gas flow rate.

The heat transfer in the hot air/ fluid section inside the pipe is at $351.1351 \mathrm{~K}$, while the convective heat transfer coefficient outside of the pipe is at 8.010580984 $\mathrm{W} / \mathrm{m}^{2} .{ }^{\circ} \mathrm{C}$, and therefore obtaining a heat transfer of $40.2312698 \mathrm{~W} / \mathrm{m}^{2} .{ }^{\circ} \mathrm{C}$.

The logarithmic mean temperature difference (LMTD) in evaporator is $35.69590751^{\circ} \mathrm{C}$ with total heat transfer area of $084178 \mathrm{~m}^{2}$. Such $2400 \mathrm{rpm}$ motor rotation obtains total heat transfer at heat exchanger which is the maximum usable heat of $0.226296111 \mathrm{~kW}$ with the effectiveness of heat exchanger at $60.95 \%$.
For the evaporating heat of motor rotation 2400 $\mathrm{rpm}$, the moisture content to be reduced in $1 \mathrm{~kg}$ of rice grain is as follows: $16.3 \%-14 \%=2.3 \%$ whereas the amount of water contained in $3 \mathrm{~kg}$ of rice grain is $2.3 \%$ x $3=6.9 \%$. Therefore, the amount of water to be reduced in $3 \mathrm{~kg}$ of rice grain is $2.3 \% \times 6.9 \%=15.87 \%$.

The energy used to evaporate the water: the amount of convective heat transfer from dry air to the product is $0.03696 \mathrm{~kW}$, and the amount of air energy used is $0.05150 \mathrm{~kW}$, obtaining the efficiency of drying tool at $71 \%$.

\section{CLOSING CHAPTER \\ Conclusion}

From the research process conducted to the design of grain drying oven using residual exhaust gas from Diesel motor, we concluded several things below:

1. The heating pipe in the oven is made according to the shape to allow the deceleration to gas velocity, so that the hot gas rate can be moved by conduction and convection into the heating chamber.

2. Styrofoam is put as a coating along the oven wall to help prevent the heat from getting out of the chamber.

3. Aluminum foil is used as a coating to maintain the chamber temperature.

\section{Suggestions}

Suggestions to give related to the research conducted are as follows:

a. Heating pipe should use copper pipe, because it is better as heat conductor.

b. To keep the heat from the motor in the pipeline: it should be wrapped with asbestos to prevent heat loss.

c. The heating chamber can be added up to 2 shelves.

\section{REFERENCES}

1. Bulog, Keputusan bersama kepala badan bimasketahanan pangan BULOG, (Oktober 2008)

2. Cengel Y. A. and Boles M. A. Property Tables Booklet Cengel Thermodynamics $6^{\text {th }} \mathrm{ed}$.

3. Design. CRC Press. Boca Raton Boston London New YorkWashington,D.C.

4. Holman. J.P. 1997. Perpindahan Kalor. Erlangga. Jakarta

5. http://www.pustaka-deptan.go.id diakses 23 november 20014.

6. http://www.pandutani.or.id/index.php/web/berita/de tail/197/Dinas-Pertanian-Merauke-BerupayaSelamatkan-Kualitas Gabah

7. Kakac, S. and Liu. H. Heat Exchangers Selection, Rating, AnaThermal. (1998)

8. Kreith, F. Prinsip-Prinsip Perpindahan Panas. Erlangga. Jakarta. (1991) 